\title{
The Policy Institutional Approach to Transport Failure in Nigeria
}

\author{
Ibrahim Adepoju Babatunde \\ City University, Phnom Penh, Cambodia \\ Email: tundes001@yahoo.com
}

How to cite this paper: Babatunde, I.A. (2020) The Policy Institutional Approach to Transport Failure in Nigeria. Open Access Library Journal, 7: e5996.

https://doi.org/10.4236/oalib.1105996

Received: December 12, 2019

Accepted: January 11, 2020

Published: January 14, 2020

Copyright $\odot 2020$ by author(s) and Open Access Library Inc.

This work is licensed under the Creative Commons Attribution International License (CC BY 4.0).

http://creativecommons.org/licenses/by/4.0/

(c) (i) Open Access

\begin{abstract}
This paper titled Policy institutional approach to transport failure in Nigeria, Encapsulating the fundamental issue and challenges that initiated transport system failure in Nigeria, despite transport sectors having immense potentials to contribute to the growth and development of the national economy. This paper examines the challenges and failure of all forms of transport system in Nigeria with a view to digress from aged long theoretical and conceptual framework to a more practical approach, in order to reduce the existing transport problem. This has been done by looking at the institutional framework and policies from post independent till date. The author researched on the paper with dependence on primary data, secondary data, textbooks, reliable internet websites and operational case study since there is a scarcity of professional material in the subject area. At the end of the paper, the presenter proposed a number of recommendations among which is the involvement of trained transport professional intransportpolicies, training, and practice, coupled with frequent review and approval of transport policy papers to reflect social, economic and environmental challenges of the country. It is believed that this research will be useful for transport policy formulator, students, researchers and also stakeholders in transport practice.
\end{abstract}

\section{Subject Areas}

Politics

\section{Keywords}

Transport, Cadre, Nigeria, System Failure, Development, Africa, Policy, Institutionalisation

\section{Introduction}

If there should be any Industrial revolution in Nigeria as it was in Britain in 1947 
(just immediately after the Second World War), it will start from the transport sectors. There seems to be in Nigeria a revolution in the agricultural sector (in other to digress from overdependence on oil as a major source of income). This economic digression appeared as a mirage, simply because the transport sectors had remained dormant as a result of breakdown of transport infrastructures and system.

Harvested and processed agricultural produce will have to be transported from the rural areas to the markets, which of course are in the cities and abroad. A critical look at the Nigerian transport system will tell that the transport sector (Ranging from the seaports, airports, railways and the roads) is sick. This is one of the major reasons why Nigeria is still classified as an underdeveloped country, since development of any country depends on how good or developed its transport system, when compared with Dubai and other oil producing countries.

It is a known and accepted fact that the beauty of a city depends on its integrated transport system, enriched by Investment policies and programs in the transport sector, which is driven by the need to rebuild the infrastructural base of the economy and to ensure an effective, efficient and integrated transportation development. It is important to achieve a sustainable transportation system in this process, based on best global practices, where sustainable means that the envisaged system is affordable, socially inclusive, environmentally friendly as well, in relation to the needs of the future generations. This is evident in Prof Bill Buchanan declaration "we are nourishing at an immense cost, a monster of great potential destructiveness, yet, we love it dearly" [1].

\section{Transport Institutional Challenges}

There had been numerous challenges in transport sector in Nigeria, which appear insurmountable as several stakeholders have recommended a lot of solutions, which are either not working or government does not believe in the solution. Some of the challenges which includes; financial constraints in transport infrastructure; inappropriate political decisions; the dearth of transport planning data; poor project implementation and to crown it all, is the corruption in the system from all quarters which is manifested in various forms, including decaying or inadequate road transport infrastructure, traffic congestion, traffic delays, accidents, and parking problems. These symptoms are heightened by flooded roadways, street hawking and inadequate or lack of road signs. Nigerian cities have failed to keep pace with the rate and speed of expansion due to population growth, this failure manifest itself [2].

Inaugural lecture given on Tuesday, June 20, 2017, by Prof. Emman Funlayo Ogunbodede, a Professor of Transport Geography. His lecture, titled, "Trading space for a cost: A Transport Geographer's view" also stated manifestation of transport failure is measured by route inadequacy; misuse of transport infrastructure; poor traffic management; absence of traffic complementary infrastructure, such as traffic signs, traffic and street lights, drainage, walkways; bus stops; and 
the upsurge in urban traffic demand without adequate measures to balance demand and supply".

Prof. Emman Funlayo Ogunbodede further recommended as a form of solution, "development of a comprehensive curriculum on road safety awareness education for road users, especially driving license applicants and traffic offenders. Such a curriculum should be offered in brochures and online, and disseminated over various media, including, radio, television, and social media. The curriculum should also be integrated into the training of the Federal Road Safety Corps and used as an instrument for educating offending motorists." [2]. Also, professor Oni "issues in and future of urban transportation and traffic; Ogunbodede, 2008 "Urban Road Transportation in Nigeria from 1960 to 2006"; Professor Patience Onakala "Transportation development in Nigeria" etc. had given a wonderful recommendation on how to solve the transport failures in Nigeria. However, I will look at the failure further from policy and institutional failure approach, so as to propose a sustainable transport solution.

\subsection{Operational Challenges Resulting in Transport Failure}

Lack of professional career development: It is very pathetic that transportation as a profession is not accorded the right attention in both public and private, which is demotivating and retrogressing practitioners in the system as per career progression. This issue is laced with the numerous challenges like unfavorable Civil service law or lack of favorable civil service reform for transport, lack of political will, ministers of transport or senior directors in ministries, state civil service commission heads, and or agencies (MDAs) are not a career or practicing transport professionals, low budget for the sector and less attention due to lack of sensitization. More than $90 \%$ of transport practitioner in private sectors does not study transport as a career profession due to either insufficient recognition of transport as a career path and/or unacceptable or unrecognizable transport institution on the part of employee, or lack of awareness of transport as an independent career pathway on the part of the employer. It is even worse in public sectors as there were no transport officer cadre (technical officer Cadres, from the GL 06 to GL 14) up to the directorate cadre (GL 15 to GL 17), in some federal and state public service. The ministries, state civil service commission and agencies (MDAs) claimed that Cadre existed only for drivers and not for senior transport professional in the public sector, as such, no transport cadre is available to take care of senior transport staff, with exception of some state civil service like Lagos and Ogunstate etc., despite all supporting federal laws. Federal government agencies like the Nigerian Institute of Transport Technology (NITT) is allegedly struggling for the approval of GL15 to GL17).

Examples of state civil service laws that recognizes transport cadre from technical officers to directorate cadre are:

1) Ogunstate TRACE Corps: This organisation has a scheme like road Traffic cadres, Road Traffic Superintendent Cadre \& Road Traffic Assistant Cadre as approved by the National Council on Establishment for adoption in Civil Service 
in Ogun State through TRACE Corps as an agency of getting adopted professional membership of IOTA (institute of transport admin and now chartered institute of transport admin) as prerequisite for the career progression of Road Traffic Officers from GL 10 and above, based on qualified experience on the job.

2) Lagos State Traffic Management (LASTMA); it is also part of Lagos State government, corporate plan of the Lagos state civil service commission, As the owner of Service Provision and Delivery (SPADEV), responsible for ensuring the performance process, appropriate recommendations of the Senior Staff Committee (SSC) for promotion, upgrading, conversion and advancement of officer on Salary Grade Levels 07 and above from all the Ministries, Departments and Agencies (MDAs) including a transport cadre without any exemption [3].

Solutions: it is a verifiable fact that one can only become an accountant in Nigeria, by passing accounting professional qualifying examinations like ICAN and ANAN etc. But Transport as a profession is slightly more complex because the ministry (despite various Civil Service Reforms introduced and implemented by different Military Governments, inherited by the current democratic Government), had established positions for transport economists and transport engineers, and other areas of transport profession were neglected;

a) There should be a cadre distinction for all phases of transport like transport Administrative cadre, transport Executive cadre and transport Engineering cadre. Lack of efficient grading and effective representation might be the major reasons why the civil service commission in various states, had been declining accent to the transport cadre, hence retrogression in training and quality of personnel and workforce.

b) Also, there should be strict regulation for recruitment into transport related organisation and roles (most especially public sector). This restriction should be similar to implementation of other professional bodies in Nigeria like ICAN for an accountant, NIA for Architect so that transport Profession can be well recognized, as obtainable in Ghana, South African and some North African Countries. This is one of the most demotivating factors for young and bright minds for studying transport management.

c) Inadequate transport institution: Manpower development is mandatory to the development of any sector, of which transport is not an exemption. But it's worrisome that Nigerian scenario does not appear to have a vision to tackle this anomaly, which had created a huge vacuum (manpower/institutional gap). More than $50 \%$ foreign professional worker still works in Nigerian territorial water and/or indigenous vessel in a country where the unemployment rate is $23.1 \%$ [4], despite Cabotage act, 2003 that mandate 100\% employment of Nigerian in maritime or sea related activities, but the law was ineffective due to certify manpower shortages [5].

\subsection{Shortage of Higher Institutions that Offers Accredited Transport Related Courses}

Shortages of transport courses like transport management, nautical science (Cap- 
tain, pilot, deck, marine cargo inspector), warehouse and distribution, material management, travel and travel logistics, engineers (marine, aviation and mechanical engineers), etc. It is rather unfortunate that, approximately 10 higher institutions offered transport related courses for a population of almost 200 million, of which institutions like MAN, NIOMR still battling with challenge of obtaining Certificate of Competence (COC) to their graduate seafarers to be employed on-board ocean-going or international vessels [5].

Below are the institutions offering transport courses in Nigeria;

1) Nigerian Institute for Oceanography and Marine Research: The Federal College of Fisheries and Marine Technology assumed its present status as a full-fledged technological institution in 1992. Before then, the College was known as the Federal School of Fisheries, which was established in 1969 as a vocational training institute to address the manpower requirement of Nigeria's fledging inshore fleet. NIOMR have departments like nautical science, Marine engineering department [6].

2) Maritime Academy of Nigeria, Oron: The Maritime Academy of Nigeria, formerly known as the Nautical College of Nigeria was established in 1977 by the Federal Executive Council No.EC. (77) 172. It was designed as an integrated institution for the education and training of shipboard officers, ratings and shorebased management personnel. The Academy, graduated its first batch of Cadets in 1983. In 1988, the scope of the college was upgraded by the promulgation Decree No. 16 of 1988 with a statutory mandate to train all levels and categories of personnel required for the effective and efficient operation of all facets of the Nigerian Maritime Industry [7].

3) Nigerian Institute of Transport Technology NITT: The Nigerian Institute of Transport Technology (NITT) was established in the year 1986 by Decree No 6 of March 14 (now CAP 116 of the Federal Laws of Nigeria). The Institute was established as a Transport Management Development and Research Institute for Nigerian and the West African Sub-region [8].

4) Federal university of technology, Akure: Offered Transport Management Technology under the department of Engineering, Environment \& Technology.

5) Federal university of technology, Minna: Offered Transport Management Technology under the department of Engineering, Environment \& Technology.

6) Federal university of technology, Owerri: Offered Transport Management Technology under the department of Engineering, Environment \& Technology.

7) Ladoke Akintola university of technology (LAUTECH): Offered Transport Management Technology under the department of Engineering, Environment \& Technology

8) Lagos state university (LASU) school of transport: Offered Transport Management Technology under the department of Engineering, Environment \& Technology. 
9) OlabisiOnabanjo University OOU, Ago Iwoye: offered transport planning and management under department of social science.

10) Nigerian Army University, Biu, Borno State-NAUB offered transport and logistics management among the 38 courses offered in 2019.

\subsection{Lack of Active National Transport Policy Statement (NTP)}

The NTP stipulates objectives to achieve sustainability in the three pillars of sustainable transport. According to World Bank [9] in the three pillars of sustainable transport are:

I) Economic and financial sustainability,

II) Social sustainability, and

III) Environmental sustainability.

The existing Draft National transport Policy, (if continuously reviewed and its objective fulfilled to reflect changes in economic conditions and social pressures.),ought to be a viable, realistic and practical response to Nigeria's requirement for an up-to-date, integrated and efficient transportation industry that can fill in as a vital gateway and connection for Nigeria's internal and external trade in manufacturing, agriculture, oil and gas, energy, and other sectors that depend on transport. The purpose of the National Transport Policy is to establish a framework that can guide the planning and development of transport activities in a systematic and sustainable manner for the social and economic development of Nigeria [10].

Mrs. Nsoroin 2017 [11], at the Meeting of the National Council on Transportation with the theme "Efficiency of Intermodalism in Transportation: Panacea for Economic Recovery" held in Sokoto on $30^{\text {th }}$ August, 2017, Council constituted the Committee to finalize the review of the draft National Transport Policy (NTP), noted that objectives defined in the policy require institutional and legal arrangements to fulfill the policy objectives. In the case of Nigeria, the last draft was published in August 2010 which needed to be reviewed continuously to reflect present economic and social pressures. The draft may not be regarded as an official policy documents for the country except after review and approval of the federal executive council (FEC) [12].

Four series of transportpolicies had been held in Nigeria till date;

I) Policy statement 1965 (which express concern about the operating condition of the Nigeria transport's system).

II) First national transport policy (NTP) in 1993 (which concerns malfunctioning of the nation's transport system and the complexities of the associated problems).

III) Draft NTP in 2003 (which concerns visible competition between transport modes, especially Road and Rail transport) and

IV) Draft NTP between 2008-2010 (which concerns decisions of government to withdraw from provisions of services including transport) [13].

Below are the agenda inherent in the last draft NTP according to federal 
government of Nigeria Draft National Transport Policy (2010) consisted of eight chapters as follows:

1) Introduction,

2) Water Transportation,

3) Land Transportation,

4) Air Transportation,

5) Education and Training,

6) Integrated Transport System,

7) Policy Implementation Arrangements and Strategic Action Plans which should provide for an integrated transport system

8) Governance and implementation strategies.

Solution: According to research conducted by Paul C.U in (2013) [14], it was established that the extent to which the Transport Policy enhances Social Sustainability in Nigeria was below the average. This implies that the policy had little or no influence in reducing the negative social impact emanating from Nigeria's Transport system, and policy modification was recommended.

For NTP to have a positive impact, it must continuously able to control Economic and financial sustainability, Social sustainability and Environmental sustainability. For this to happen; the following steps are necessary;

- Identify transport need or gap.

- Identify who will take lead responsibility (delegate to stakeholders and professional in transport related).

- Gather information (accurate and verifiable data from federal, state ministry of transport and private sectors).

- Draft policy (continuously review to reflect changes in economic conditions and social pressures).

- Consult with appropriate stakeholders (stakeholder support to identify potential opportunities and threat of policy).

- Finalize/approve policy (FEC review and approval or any other government authority saddled with such responsibility).

- Consider whether procedures are required (clear guidance regarding how the policy will be implemented and whose responsibility-internal policy positions).

- Implement (How will the policy be communicated and to whom-external policy positions).

- Monitor, review, revised (control, monitoring, reporting systems, reviewed and revised (if necessary) [15].

\subsection{Lack of Integrated Transport Infrastructure Master Plan}

Initial infrastructure design was conceived poorly or was used for another purpose contrary to its initial plan by the colonial masters, coupled with the absence of day to day infrastructural development that will match up with the growing population. One of the major transportation problems in Nigeria is the inade- 
quate integrated intermodal system like railroads. The absence of utilitarian railways interfacing the ports to significant urban areas has constrained merchant to transport their merchandise and product completely by road, this means the roads have to bear the extra load of haulage trucks and petrol tankers across long distances, leading to traffic jams and other inconveniences for road users.

- The railway system in Nigeria was built during the colonial era and have been poorly maintained since then, the Nigerian railways system was also designed to transport agricultural and mineral resources from inland areas straight to the ports (down south) for export overseas (Walter R, 1972), but recently the Nigerian government with the help of the Chinese have begun working on building new railroads, designed to facilitate trade and commerce between Nigerian cities, most notably; the recently completed Kaduna-Abuja railways.

\subsection{The Most Glaring and Challenging Problem for Transport Networks Are Poor Road Design}

Most of the truly bad roads in Nigeria are in areas with high water tables or flooding problems. These areas are completely wrong for asphalt surfacing. Asphalt in water logged areas requires many and multiple expensive repairs that don't last long, however, surface treatments or thin overlays every $7-10$ years can extend that to 20 years between major work. It is much cheaper to keep a good road in good repair than it is to rebuild a poor road [16].

Solution 1: A better option would be concrete surfacing; this would reduce the rate of depletion and deterioration by almost $80 \%$. Most especially, port access roads, which almost always deteriorate immediately after being repaired. Same concrete surfacing is being explore now in Apapa Oshodi express way by a Hitech construction company.

\section{1) For Rail network}

The major challenge is refusal to downgrade: It is a general knowledge that Nigeria as a nation, cannot afford modern rail for most parts of the country, due to the economic status of the nation and debt financing-based budget. Rather than buying cheap small, inefficient diesel locomotives, building cheaper, but slower narrow-gauge tracks will be more effective. Nigeria fruitless struggles of modern or high-speed rail or to cover the project of the entire country at once. Contractors then quote high prices, or cheap prices for substandard rail.

Solution 2: Utilize small, efficient trains for goods only. Build depots near the most major population centers, but out of town. Only build high speed rail in Lagos, Abuja and PHC or any strategic city and the government need to have a long-term strategic plan for projects, rather than rushing project with substandard material

\section{2) For Air transport}

Air transport contributes approximately $2.4 \%$ of global GDP [17], which Nigeria yet to have her share, due to inefficient air policy. For example, Nigeria 
built large, expensive airports, even though no effort is taken to make them transport hubs (To link 54 countries in African continents as the giant of Africa directly, through "point-to-point"). Since many African Countries (airline and commuter if right policy is implemented) will Like to Fly to/From Nigerian Airport (for related voyage), either due to population traffic from Nigeria or numerous economic activities. Hence, this will serve as revenue directly or indirectly to her people and government.

Solution: Build or preferably license short runway airports with cheap tariffs, which may take a little longer. Rather than 100 - 200-seater planes requiring expensive airports. Build cheap small airports that only 25 - 50-seater planes can land in, charge only the barest tax possible. Make agreements with neighboring countries (taking advantage of ECOWAS), Fly 2 - 4 hours flights, instead of 1 hour voyage. This avoids white elephant projects and the country can build closer to the city centers. A very good example to buttress this, is a Case study of China building some modest rail capacity despite their financial muscles. Air traffic is decent, with multiple domestic carriers (as many or more than we commonly see in America, where often a single or, at most two or three carriers dominate many routes).

Summarily, privatization or commercialization options might also serve as sustainable option, for Nigerian infrastructural development.

\subsection{Traffic Management}

Traffic congestion has become a common sight in most urban cities of Nigeria. This is identified to be as a result of poor driving habits, inadequate road capacity, unplanned population, a poor road network, lack of parking facilities. Inadequate formal modes, inadequacy of infrastructure, and insufficient land use pattern. Lagos, Port Harcourt and Abuja were identified as the cities most affected by traffic congestion. Lagos Population has continued to grow at a rate of $3.2 \%$ per annum. Present population is above 23 million and was also forecasted to bring the daily demand for trips to about 40 million/day by 2032 [18].

97.5\% passenger trip per day were purely by road while walking, train and water transport shared $40 \%, 1 \%$ and $0.34 \%$ respectively as indicated in Chart 1 . This shows that the major reason for congestion is because Lagos passengers commute purely by road [19].

One wonders why the congestion on Lagos road is unpredictable throughout the week except sometimes on Thursday, between $7 \mathrm{am}-10$ am (Sanitation days). It could be safe to say that self-employed labourforce (74.58\%) are the major cause of traffic congestion in Lagos. There will be a peak period if all sectors of labour force come out almost the same time with salary workers (25.42\%) - either private or public sectors according to the National bureau of statistics: [20].

Also, a larger percentage of salary workers (25.42\%) own and drive their cars in Lagos, most especially Private Cars estimated to be $11 \%(2,508,000)$ as illustrated in Chart 2. This is due to the poor condition of public transport (SemiFormal Mini Buses-Danfos) as the regulated (BRT, LAGBUS) will be insufficient 
which could only convey $1.41 \%$ of $11 \%$ of the comfort craving workforce (private car users), leaving a deficit of $9.59 \%$ [20].

Some of the benefits of using public transport are below:

- Its benefits communities financially:

- Public transportation reduces air pollution:

- Increased fuel efficiency:

- Reduced traffic congestion:

- Saves money:

- Increases mobility:

- Frees up time: Transit time can be used for reading, working, studying, entertained etc.

- Public transportation is safer:

- Encourages healthier habits:

\section{Solutions:}

- Government support for mass public transport, with consideration of safety, security and acceptable journey time, while comfort can be in grades, based on cost.

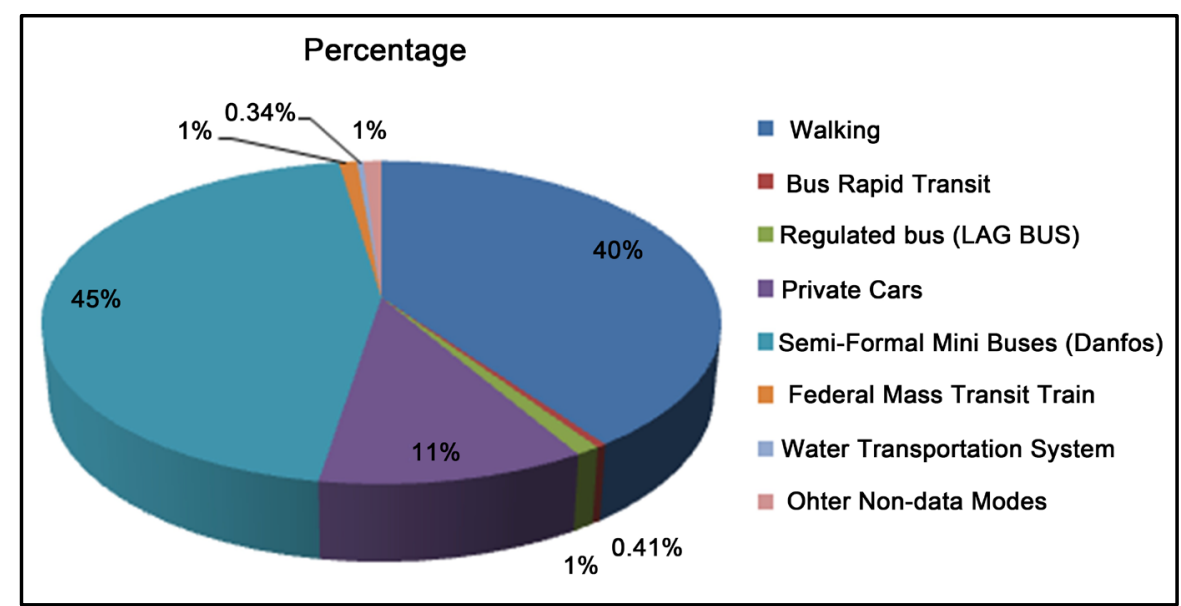

Source: authors' field work adapted from Lagos Metropolitan Area Transport Authority, 2015.

Chart 1. Passenger Traffic per Day in Lagos.

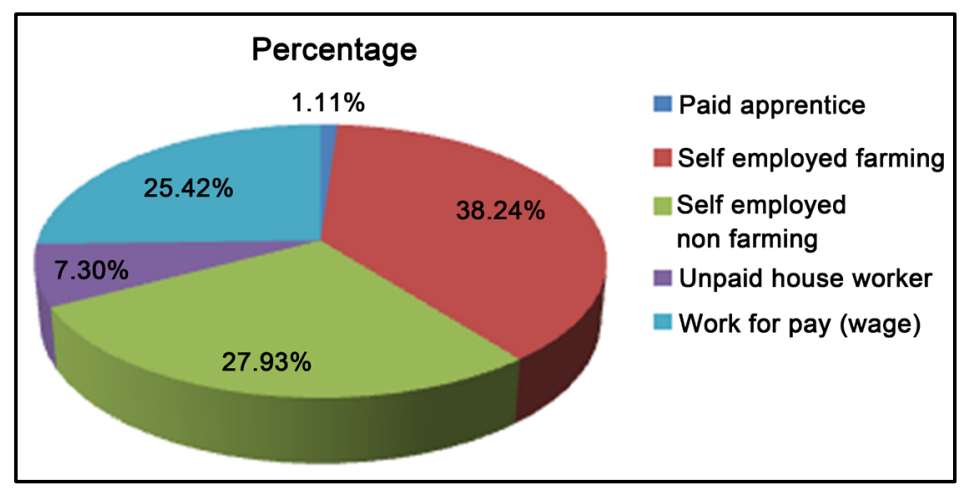

Source: adapted from National bureau of statistics.

Chart 2. Labour Force Statistics (Employment by Sector Report Q3 2017). 
- Stager or juggling of the commuter's movement time, for example: Private labour force might set out by 8 am, Public 9 am, others from $10 \mathrm{am}$. This will help to manage congestion based on the available regulated public transport.

- This will help to manage congestion based on the available regulated public transport.

- Set congestion prices on commuters taking their private cars into Central business districts (CBDs) or high concentration of industries or high traffic movement areas.

- Effective traffic law and enforcement.

- Safe car park.

- Encourage intermodal transport.

\section{Data Analysis}

It should be noted that of all the mode of transport available in Nigeria namely Maritime, Rail, Road, Air, Mail, Multimodal, inland water ways, maritime (containerised) constitute $95 \%$ of total import while air constitute the remaining $5 \%$ (as illustrated in Chart 3), while other modes have insignificant figure. it should be note that in Q3, 2018 the major component imported were 27.78\% Floating or submersible drilling or production platforms, $20.48 \%$ of Motor Spirit ordinary, $1.98 \%$ Gas Oil, $1.76 \%$ Used Vehicles, with diesel or semidiesel engine, of cylinder capacity $>2500 \mathrm{cc}, 1.39 \%$ Durum wheat (Not in seeds), $1.10 \%$ Cane sugar specified in Subheading Note 2 to Chapter 17, Meant for sugar refinery, $1.04 \%$ Durum wheat, Seed, $0.99 \%$ Imported motorcycles and cycles, imported CKD by established manufacturers $>50 \mathrm{cc} \leq 250 \mathrm{cc}, 0.99 \%$ Other instruments and apparatus, for medical, surgical sciences, while others are less than $0.99 \%$. The maritime distribution by port are seen in Chart 4 .

Apapa port is the most business port in Nigeria with $68.17 \%$ patronage follow by Tin Can Island 13.51\% Port Harcourt (3) 4.69\% Muhammed Murtala Cargo 3.95\%, Tincan Bonded Ware/House 2.98\%, Port Harcourt (1) 1.06\%, Kirikiri Lighter Terminal Cmd 0.99\%, Lilypond Port 0.77\%, Warri Port 0.73\%, Kano Airport 0.71\%.

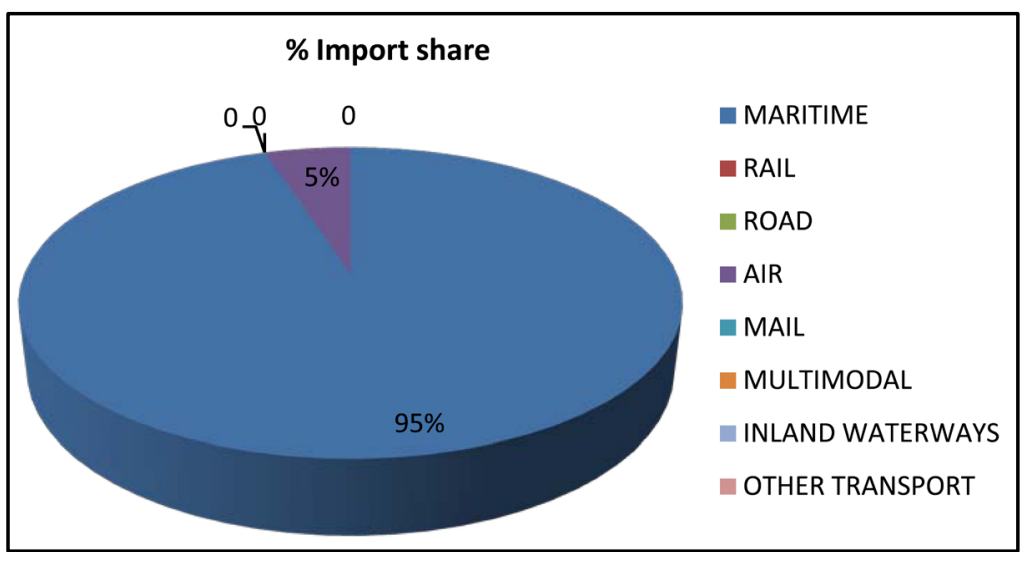

Source: Authors' field work adapted from National bureau of statistics 2018.

Chart 3. Import mode implored is Nigeria 2018. 
Economic Region, Agric Sector, Raw material, Solid Mineral, Energy sector, Manufacturing, Crude oil and Others with import for Africa having $96 \%$ for energy sector, $65 \%$ solid mineral and $55 \%$ manufacturing with $1 \%$ export of Agric commodity as indicated in Figure 1.

Also, for import Africa had 20\% solid mineral, $11 \%$ raw material and Agric $8 \%$, manufacturing had $2 \%$ while other sectors had $3 \%$.

It is to be noted that either import or export process constitute more than $90 \%$ transport related and as such, improvement in transport facility will develop other sector of the economy, and will also improve export and import as cost of goods will reduce to encourage local manufacturer to compete with foreign imported goods as indicated in Figure 2.

We could conclude that the $\mathrm{CHI}$ square test carried out on secondary data was not significant at 0.13 level (2-tailed p. $>0.0005)$ of significance. $\left(\mathrm{X}^{2}=24, \mathrm{df}=\right.$ 42). P-value $>0.05$ (as symbolized in Table 1 ); indicates weak evidence against the null hypothesis (The P-value is not significant, indicating that there is no association between the variables) so we conclude that there is no significance difference between transport efficiency and economic development.

In summary, we accept the null hypothesis that says transport policy institutional

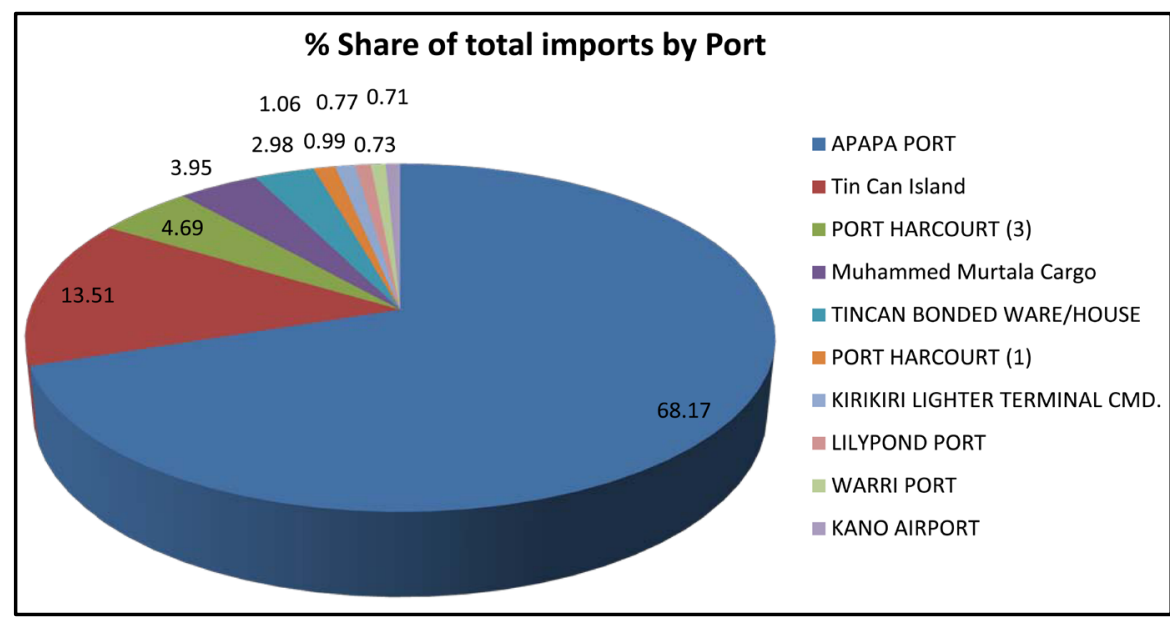

Source: Authors' field work adapted from National Bureau of statistics 2018.

Chart 4. Maritime importation distribution by port.

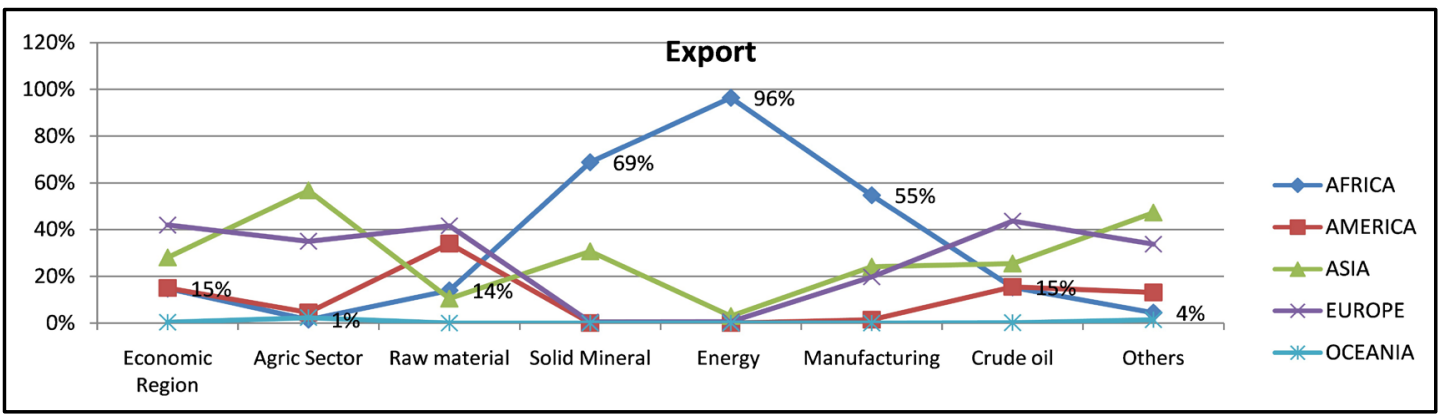

Source: Authors' field work adapted from National Bureau of statistics 2018.

Figure 1. Sectorial export to economic regions of the world (N'million) Q3, 2018. 


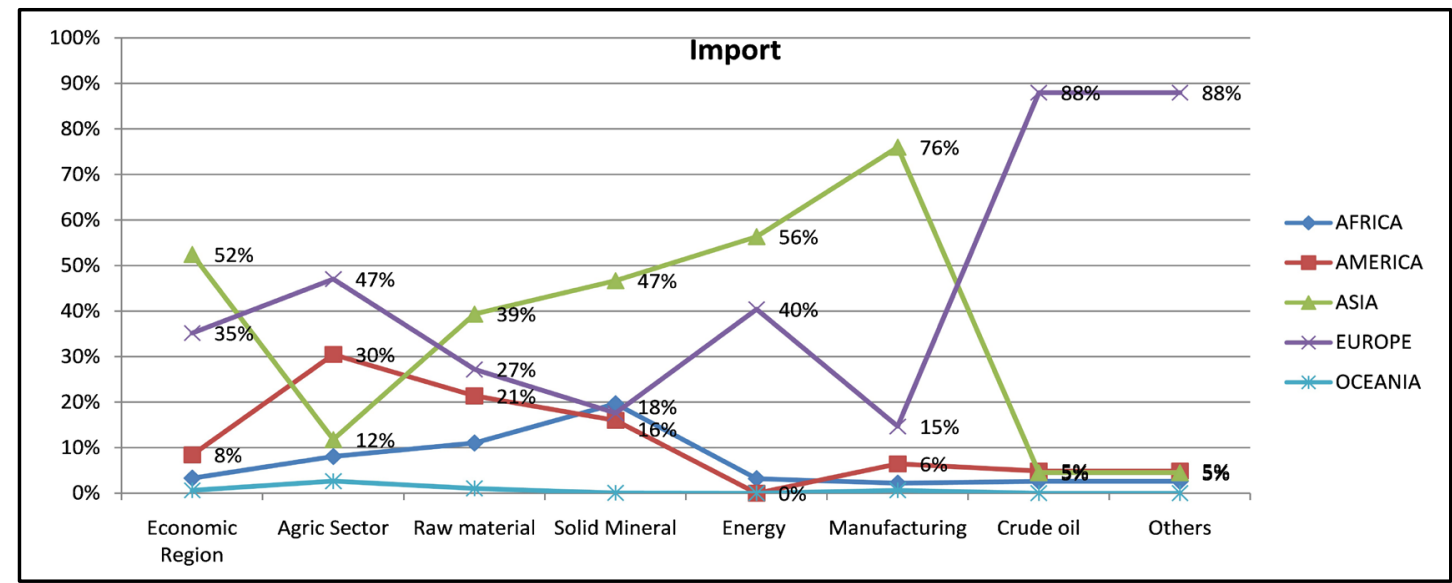

Source: Authors' field work adapted from National Bureau of statistics 2018.

Figure 2. Sectorial imports to economic regions of the world (N'million) Q3, 2018.

Table 1. Chi-square, directional measure and symmetry measures.

Chi-Square Tests

\begin{tabular}{cccc}
\hline & Value & df & Asymptotic Significance (2-sided) \\
\hline Pearson Chi-Square & $48.000 \mathrm{a}$ & 42 & 0.243 \\
Likelihood Ratio & 30.498 & 42 & 0.906 \\
N of Valid Cases & 8 & & \\
\hline
\end{tabular}

a. 56 cells $(100.0 \%)$ have expected count less than 5 . the minimum expected count is 13. Source: Authors' SPSS analysis

Directional Measures

\begin{tabular}{|c|c|c|c|c|c|c|}
\hline & & & Value & $\begin{array}{c}\text { Asymptotic } \\
\text { Standardized } \\
\text { Error• }\end{array}$ & $\begin{array}{c}\text { Approximate } \\
\mathrm{Tb}\end{array}$ & $\begin{array}{r}\text { Approximate } \\
\text { Significance }\end{array}$ \\
\hline \multirow{11}{*}{$\begin{array}{l}\text { Nominal } \\
\text { by } \\
\text { Nominal }\end{array}$} & \multirow[t]{4}{*}{ Lambda } & Symmetric & 0.923 & 0.076 & 6.000 & 0.000 \\
\hline & & Sector Dependent & 0.857 & 0.132 & 4.899 & 0.000 \\
\hline & & percent export & 1.000 & 0.000 & 4.899 & 0.000 \\
\hline & & Dependent & & & & \\
\hline & \multirow{3}{*}{$\begin{array}{c}\text { Goodman and } \\
\text { Kruskaltau }\end{array}$} & Sector Dependent & 0.857 & 0.000 & & $0.471 \mathrm{c}$ \\
\hline & & percent export & 1.000 & 0.000 & & $0.471 \mathrm{c}$ \\
\hline & & Dependent & & & & \\
\hline & \multirow{4}{*}{$\begin{array}{l}\text { Uncertainty } \\
\text { Coefficient }\end{array}$} & Symmetric & 0.957 & 0.028 & 17.963 & $0.906 \mathrm{~d}$ \\
\hline & & Sector Dependent & 0.917 & 0.051 & 17.963 & $0.906 \mathrm{~d}$ \\
\hline & & percent export & 1.000 & 0.000 & 17.963 & $0.906 \mathrm{~d}$ \\
\hline & & Dependent & & & & \\
\hline \multirow{4}{*}{$\begin{array}{c}\text { Ordinal by } \\
\text { Ordinal }\end{array}$} & \multirow[t]{4}{*}{ Somers' d } & Symmetric & 0.255 & 0.286 & 0.893 & 0.372 \\
\hline & & Sector Dependent & 0.259 & 0.291 & 0.893 & 0.372 \\
\hline & & percent export & 0.250 & 0.280 & 0.893 & 0.372 \\
\hline & & Dependent & & & & \\
\hline
\end{tabular}

a. Not assuming the null hypothesis. b. Using the asymptotic standard error assuming the null hypothesis. c. Based on chi-square approximation. d. Likelihood ratio chi-square probabilitv. Source: Authors' SPSS analysis. 
efficiency will lead to economic development based on the secondary data gotten from National Bureau of statistics, although 9 sectors were measured which are; (Economic Region, Agric Sector, Raw material, Solid Mineral, Energy, Manufacturing, Crude oil and Others), of the different sector measured for export, 5 continents were our reference point; Africa, America, Asia, Europe, Oceania to check for efficiency per continent on the 9 sectors. It was discovered that, Africa did badly on key economic indicator indices (Like Agric, manufacturing) but cover up in the area of export of mineral resources like oil and gas, which they have in excess (this is not sustainable as many exporter of this petroleum product are divesting from petrol to alternative sources of energy like electricity). Although SPSS may not take into consideration, all these parameters (SPSS only shows that the null hypothesis that African transport policy institutional efficiency supported economic development).

The assumption is that if a particular sector is not doing well, then transport might likely be responsible. This assumption for Africa is based on the fact proven by Adepoju I.B, (2019) [21] "for supply chain constitutes 50\% of Agric value chain while Agric and finance related input shared the remaining 50\%." and almost $50 \%$ of fruit and vegetable produced in Nigeria is lost after harvest, largely due to poor transport network, according to research conducted by Adepoju IB, (2019) [22]. This perishable fruit were wasted before getting into sales market (Lagos) and excess fruit unconsumed are also wasted because of poor transport policy to export to country of scarcity or area where it is needed.

Lastly, the percentage share of Africa export/import with five major trading partners Q3, 2018 might be seen as an improvement in the balance of trade, even if Africa is the least among the 5 trade partners, but improvement is as a result of south African's improved export, and Nigerian improved import.

\section{Conclusions}

1) Summarily, decaying transport infrastructure caused by Poor maintenance culture is a general menace steering on all modes of transport in Nigeria, coupled with government interference, even when it is visible that government active participation will not be effective. Rather commercialization or privatization will revolutionize the sector.

2) Too much pressure on the few good transport facilities, in addition to the growing population. Over-reliance on only one mode instead of utilization of intermodal transport, which have left reason why there are many cars on the road and none on trains and ferries.

3) Lack of initiative to invest. This is the reason why cruise boats, monorails and underground Subways sound like a myth due to unfavourable and unstable government economic and political policies. Culture of individual owning their cars and want to put it on the road (40.67\% private cars move daily), is another challenge, since public transport is assumed to be less convenient and comfortable (for the upper and middle class). Although, Public transportation in Lagos is 
poised to assume a revolutionary phase among dominant service provider within the mass transit sector in Nigeria, with the introduction of Bus rapid transit (BRT).

4) Corruption is another glaring challenge: Ease of doing business, Obtaining licenses and permits, Multiple taxes by federal, state and local government, Bribing government officials (FRSC, VIO, LASTMA etc.) and forceful extortion of money from commercial motorist by NURTW/RTEAN with no economic impacts, had made it difficult for investors and entrepreneurs to invest in capital intensive transport infrastructure.

5) Manpower development: This is the area of teaching practical oriented transport courses in Nigerian university and professional qualification in all facets of transport, like mandatory international courses for sea and air workers and professional qualification like Royal chartered, chartered institute of Logistics and Transport (CILT) and the recently approved professional body by the federal government of Nigeria-Chartered Institute of transport administrator (CIOTA) which act was recently enacted. CIOTA should serve as an institution to champion building a reputation of a world class institute of transport administration by providing and advancing top notch study, training, certification and practice of transportation management and administration in Nigeria and other related matters as reported by Theodore Opara 2019 [23].

6) Over reliance on one mode as $97.5 \%$ Passenger trip per day were purely by road (walking inclusive), while train and water transport shared the remaining 2.5\%. Hence, the Road wears and tears more often [19].

\section{Recommendations}

1) Efficient maintenance of transport infrastructure (air, sea, rail, road) with appropriate finance option to divest asset to strategic investor in order to relief government of burden of capital-intensive budgetary allocation on transport infrastructure like toll payment, PPP, privatization and commercialization.

2) Merging together of CIOTA and CILT to take advantage of standard training, evaluation, assessment and exam process of CILT, coupled with the international recognition (if name is retained), while CIOTA act will give full legal backup locally to form a formidable force to be recon with.

3) Encouragement of mandatory recruitment of only qualified and licensed professional like carrier of CIOTA, CILT, and NITT for private and compulsory upgrade of level GL8 as an entry point for carrier of CIOTA as enshrined in CIOTA act.

4) Exploration of integrated intermodal transport to address severe congestion in Lagos, most especially areas like air \& sea ports, port access road, central business district $(\mathrm{CBD})$ in order to reduce shipping costs, waste of productive time and commuting lead time for passenger transport, as well as connects $\mathrm{Ni}$ geria's hinterland to global markets to diversify its economy for cargo transport,

5) Sensitization of federal, state and local government on the importance of 
transport to economic development and establishment of the transport Cadre from technical to directorate level.

6) Regular review of National transport policy to reflect social, economic and environmental pressure and appropriate approval to endorse it for implementation.

7) All transport related non-governmental agencies like NURTW, RTEAN must be re-trained and certify on regular basis, while governmental and private firm must also participate in mandatory top up courses.

8) Equipping NITT state-of-the art technology and equipment for transport Research and development like a self-automated truck, automated and robotic warehouse for training and simulation.

9) More practical oriented university to train transport management student, and also relevant international certification for seafarer who want to be mobilized on foreign vessel or aircraft and also Nigerian policy makers should ensure to implement people friendly laws and strategies for both indigenous and foreign investors in the transport sector.

10) Alternating commuter's movement time, for example; Private labour force set out by $8 \mathrm{am}$, Public $9 \mathrm{am}$, others from $10 \mathrm{am}$. This will help to manage congestion based on the available regulated public transport.

11) Implementation of congestion levies on commuters taking their private cars into Central business districts (CBDs) or high industries concentration or high traffic movement areas.

12) Government support for mass public transport, with consideration of safety, security and acceptable journey time, while comfort can be in grades, based on cost.

\section{Conflicts of Interest}

The author declares no conflicts of interest regarding the publication of this paper.

\section{References}

[1] IOTA Research Council (2018). https://blog.iota.org/iota-research-council-bdfb73125e

[2] Akinnaso, N. (2017) A Transport Geographer's View of Nigeria's Transport Problems.

[3] Lagos Corporate Planning Report. http://www.sparc-nigeria.com/RC/files/3.2.21_Lagos_Corporate_Plan_MoETP.pdf

[4] The National Bureau of Statistics (NBS) (2017) http://nigerianstat.gov.ng/elibrary?queries[search]=trade

[5] Adepoju, I.B. (2019) Cabotage Operations between Theory and Practice in Nigeria. Electronic Research Journal of Social Sciences and Humanities, 1, 124.

[6] Marine College. http://marinecollege-edu.org/history.html

[7] Maritime Academy of Nigeria. https://www.maritimeacademy.gov.ng/

[8] Nigerian Institute of Transport Technology. 
https://www.nigerianseminarsandtrainings.com/tprovider/132/Nigerian-Institute-o f-Transport-Technology

[9] World Resources Institute (2004) http://pdf.wri.org/wr2002_fullreport.pdf

[10] https://www.transportation.gov.ng/index.php/9-uncategorised/232-report-on-finali zation-of-draft-national-transport-policy-ntp

[11] Nsoro, M. (2017) At the Meeting of the National Council on Transportation with the Theme "Efficiency of Intermodalism in Transportation: Panacea for Economic Recovery. Sokoto, 30 August, 2017, Council Constituted the Committee to Finalize the Review of the Draft National Transport Policy (NTP).

[12] Agabi, C. (2017) FG Receives Final Draft of National Transport Policy. https://www.dailytrust.com.ng/fg-receives-final-draft-of-national-transport-policyh $\underline{\mathrm{tml}}$

[13] Femi, S.A.G. (2019) Building Sustainable Policy Framework for Transport Development: A Review of National Transport Policy Initiatives in Nigeria. International Journal of Development and Sustainability, 2, 505-520. https://www.isdsnet.com/ijds

[14] Ugboaja, P.C. (2013) A Sustainability Assessment of Nigerian Transport Policy. International Journal of Asian Social Science, 3, 1208-1226

[15] Development Policies and Procedures. https://www.diycommitteeguide.org/resource/how-to-develop-policies-and-proced ures

[16] 100 Asphalt Institute. http://www.asphaltinstitute.org/

[17] ATAG (2004) https://www.w3.org/2004/09/wai-nav/atag

[18] Lookmanoshodi (2016) International Development, Urban Infrastructure and Governance.

https://oshlookman.wordpress.com/2016/08/12/transportation-and-mobility-syste $\underline{\text { m-in-lagos/ }}$

[19] Lagos Metropolitan Area Transport Authority (2015). https://lamata-ng.com/

[20] National Bureau of Statistics: Employment by Sector Report Q3 (2017) https://www.proshareng.com/admin/upload/report/10910-ProshareConfidentialDe cember2017-proshare.pdf

[21] Adepoju, I.B. (2019) Impact of Supply Chain in Reducing Fruit Post-Harvest Waste in Agric Value Chain in Nigeria. Electronic Research Journal of Social Sciences and Humanities, 1. https://www.eresearchjournal.com

[22] Adepoju, I.B. (2019) Free Trade Zones between Theory and Practice in Nigeria. IOSR Journal of Humanities and Social Science, 24, 52-68.

[23] Theodore Opara (2019) Theodore Opara. The Privacy Policy Vanguard. 